\title{
Do students of dance schools show orthorexic behaviours?
}

Mateusz Grajek

Medical University of Silesia

Karolina Krupa-Kotara ( $\sim$ kkrupa@sum.edu.pl)

Medical University of Silesia

Agnieszka Białek-Dratwa

Medical University of Silesia

Krzysztof Sas-Nowosielski

The Jerzy Kukuczka Academy of Physical Education in Katowice

Article

Keywords: orthorexia nervosa, ballerinas, eating disorders, physical activity, sport

Posted Date: March 28th, 2022

DOI: https://doi.org/10.21203/rs.3.rs-1342931/v2

License: @) (1) This work is licensed under a Creative Commons Attribution 4.0 International License. Read Full License 


\section{Abstract}

Introduction. Many studies have shown that a group of people practicing sports, including those representing sports disciplines that require a slim figure and flexibility, is exposed to an increased risk of orthorexia nervosa (ON). Due to great difficulties in making the final diagnosis, the exact number of people suffering from orthorexia is still unknown.

Aim. The study aimed to assess the risk of orthorexic behavior in the group of girls attending ballet schools. The essence of the study was to analyze the anthropometric indicator and eating habits and to correlate them with the obtained risk indicator of orthorexic behaviors.

Material and method. The investigated group consisted of 800 female students (10-18 years old) who attended ballet schools in Poland (Silesia). At the beginning of the study, anthropometric measurements of the examined students were performed and a detailed nutritional interview was conducted with them. The dietary habits of the research group were evaluated by the diet quality index (DQI). To assess the risk of orthorexic behaviors, an ORTO-15, and ORTO-15 PL questionnaires were used. The collected data were statistically analyzed (the Statistica 13.0 package was applied). The degree of probability was 0.05 .

Results. Based on the DQI it was found that $44 \%$ of all respondents reported good, $36 \%$ - satisfactory, and $20 \%$ - bad eating habits. The genuine risk of eating disorders was observed among 65\% (ORTO-15) and 59\% (ORTO-15 PL) of subjects. This included students with good dietary habits $(65 \%)$ and $73 \%$ of students who considered themselves to be obese. Statistical inference showed a relationship between the positive result obtained in the ORTO-15 questionnaire and participants' incorrect perception of their own body $(\mathrm{p}<0.05)$. Moreover, it was noted that higher scores in both ORTO scales were obtained by girls whose $\mathrm{BMI}(62 \%)$ and \%BF (56\%) were in the correct range.

Conclusion. This is particularly visible in the group of girls whose eating habits were assessed as good and in the group of ballerinas who consider themselves obese. Moreover, it was noted that BMI and adipose tissue level in the risk group was at the correct level.

\section{Plain English Summary}

Many studies have shown that a group of people practicing sports, including those representing sports disciplines that require a slim figure and flexibility, is exposed to an increased risk of orthorexia nervosa (ON). Due to great difficulties in making the final diagnosis, the exact number of people suffering from orthorexia is still unknown. The aim of this study was to assess the risk of orthorexic behavior in the group of girls attending ballet schools. The essence of the study was to analyze the anthropometric indicator and eating habits and to correlate them with the obtained risk indicator of orthorexic behaviors. This is particularly visible in the group of girls whose eating habits were assessed as good and in the group of ballerinas who consider themselves obese. Moreover, it was noted that BMI and adipose tissue level in the risk group was at the correct level.

\section{Introduction}

Many studies have shown that a group of people practicing sports, including those representing sports disciplines that require slim figures and flexibility, is exposed to an increased risk of orthorexic behavior [1-6]. Due to great difficulties in making the final diagnosis, the exact number of people suffering from orthorexia is still unknown [1, 2]. Dunn and Bartman [3] estimated that there may be between $6 \%$ and $9 \%$ of patients, depending on the professional group. People suffering from orthorexia are often treated by their surroundings to care about their health. The lack of precise data on the scale of the problem is also due to the reluctance of the orthorexic to report to specialists [4]. As a result, there is no mention of this condition in the International Statistical Classification of Diseases and Related Health Problems (ICD) and Diagnostic and Statistical Manual of Mental Disorders (DSM). Orthorexia is an eating disorder that was first described in 1997 [5]. This is a relatively new diagnosis consisting of a pathological obsession with healthy food, which in consequence leads to neglecting other life activities. A person with the diagnosis of orthorexia, thanks to maintaining a strict diet, feels a sense of control over his/her life [2]. Orthorexia in the general population is estimated at $7 \%$ and affects men more often [2]. Turkish research confirms the view that orthorexia affects specific sport and health-related groups. The results of a study showed that as much as $45.5 \%$ of medical 
students out of 318 respondents showed characteristics of orthorexia [6]. The person with the diagnosis of orthorexia differs from anorexia in the fact that the former are not obsessed with maintaining a slim figure [4]. Any deviation from the planned diet, the appearance of a mistake in nutrition is burdened with fear. Obsessive fear, on the other hand, will impose the avoidance of reaching for food whose composition is unknown. Among the factors predisposing to the development of this disorder is an abnormal attitude to food, obsessive-compulsive behaviour, and low body mass index (BMI) values [1, 2]. Orthorexia can lead to exhaustion of the body and pose a threat to life, so nutrition education on proper nutrition is essential.

A special group that deals with young people practicing aesthetic sports, such as students of dance schools, including ballet schools. According to Bartel et al. [7], the two biggest symptoms of orthorexia are when a dancer restricts her eating to the point that she is not getting enough nutrients, and when someone shuts down socially and stops eating because she is unsure of the composition of the food. The problem of orthorexia begins when the consequences of food choices become decidedly unhealthy. There is nothing wrong with wanting to be in shape or healthy, but orthorexia begins when the behavior becomes extremely restrictive. Bartel, on the other hand, states that many orthorexics experience a snowball effect - the rules become stricter and stricter until they end up eating almost nothing.

Therefore, the study aimed to assess the risk of orthorexic behavior in the group of girls attending ballet schools. The essence of the study was to analyze the anthropometric indicator and eating habits (related to the quality of nutrition) and to correlate them with the obtained risk indicator of orthorexic behaviors.

\section{Material And Methods}

The investigated group consisted of 800 female students (10-18 years old) who attended ballet schools in Poland (Silesia). The study involved female students from 20 schools, which were selected through an independent lottery. The assumption was to a proportional selection of schools to represent different parts of the country. The students gave their informed consent to participate in the study (in the case of minors, such consent was given by their parents / legal guardians). The study was conducted without direct contact, based on a questionnaire interview, therefore the consent of the Bioethics Committee was not required. All data was collected anonymously.

At the beginning of the study, anthropometric measurements of the examined students were performed and a detailed nutritional interview (consisting of questions about basic eating habits and a food diary) with a survey of physical activity was conducted with them. The data was collected based on a questionnaire interview and consisted of the participant's declaration. The dietary habits of the research group were evaluated by the diet quality index (DQI) (Table I). The usefulness of DQI in Polish conditions has been confirmed in studies including by Kubiak et al. [8] and Frackiewicz et al. [9]. To assess the risk of orthorexic behaviors, an ORTO-15, and ORTO-15 PL questionnaires were used. The questionnaires were applied twice to validate the obtained results. The participants agreed to participate in the survey. To select the age group most exposed to orthorexia, the study group was divided into three sections: $10-12$ years (34\%); $13-15$ years (38\%), and $16-18$ years (28\%).

Table I. Diet Quality Index (DQI) 


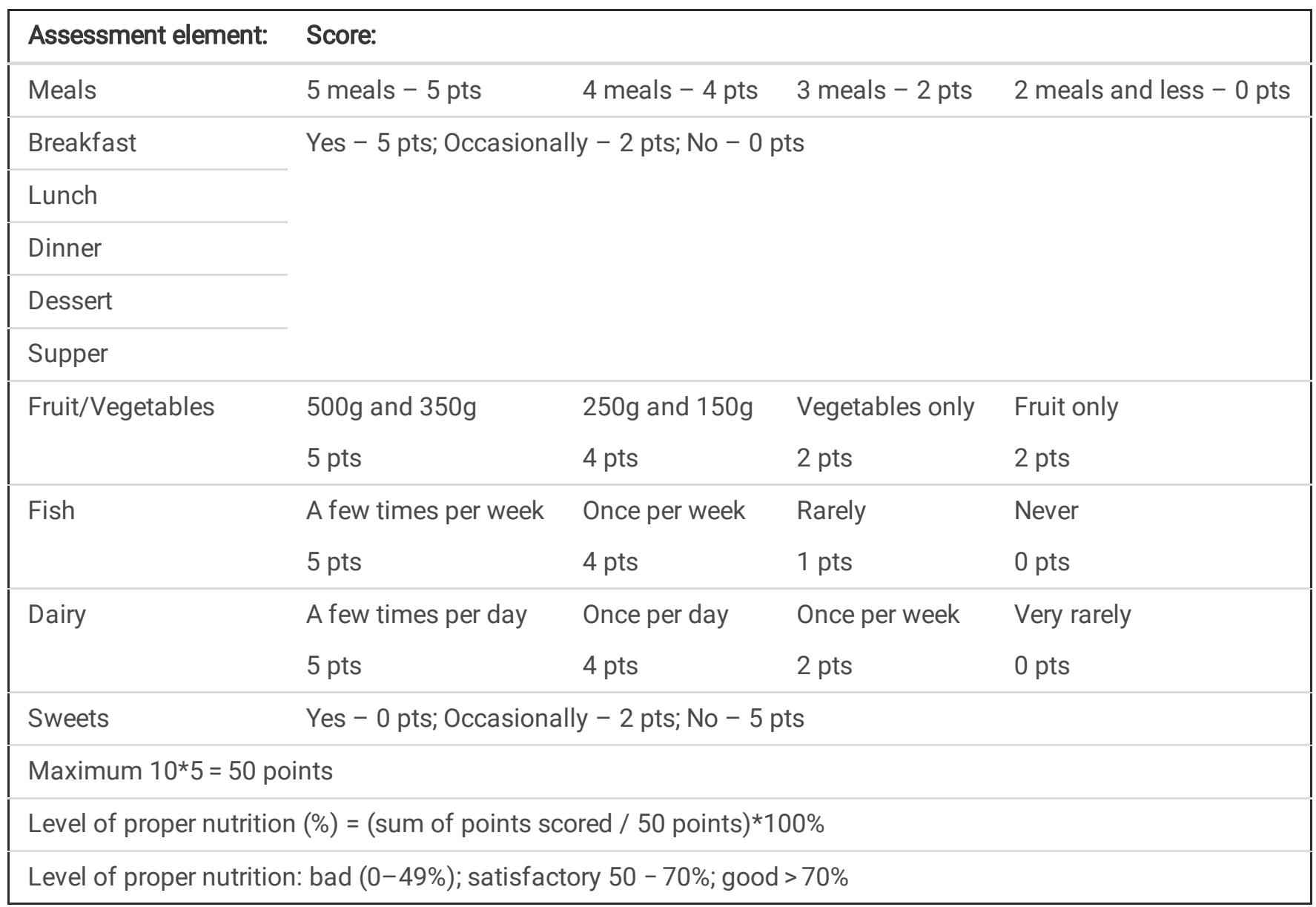

To assess the risk of orthorexia among the studied group, the ORTO-15 questionnaire was used in the survey [10]. It consisted of 15 questions concerning the selection, purchase, preparation, and consumption of food that was considered healthy. The respondents answered the questions using a four-point Likert scale, i.e., from always to never. Each answer was assigned the following points: 1 - always, 2 - often, 3 - sometimes, 4 - never. The value of 40 points was assumed as a cut-off point. The score below this value indicated a tendency to orthorexic behavior. The questionnaire was also translated and adapted to Polish conditions (ORTO-15 PL) by Brytek-Matera et al. [11] It included 9 questions containing cognitive (6 questions) and clinical (3 questions) factors. The cut-off point was set at 24 points. The score below this value was indicative of a tendency to orthorexia. To confirm the obtained results, the point range from the Polish version of the ORTO-15 questionnaire was also used in this study.

The collected data were statistically analyzed (the Statistica 13.0 package was applied). The collected anthropometric data were used to calculate the BMI which were then compared with the current WHO recommendations. The same was done with data on diet. Data collected from three-day food diaries were analyzed in the Diet 6.0 program (a program recommended by the National Center for Nutrition Education, compliant with WHO). The data on anthropometric indices and the results of the nutrition quality assessment were subjected to statistical analysis, and then they were correlated with the results obtained according to the ORTO-15 and ORTO-15 PL scales. An intergroup comparison was conducted using variance analysis along with post-hoc tests (Scheffé test). When it comes to failed research assumptions, tests' nonparametric equivalents were used instead (Mann-Whitney U test, ANOVA Kruskal-Wallis test, and chi-square test) including the multiple comparisons of the mean value for ranks in every testing and corrections for the conducted tests. The direction and strength of correlation between two quantitative variables were estimated using the regression equation and Pearson correlation coefficient. Kappa test was used to estimate the data reliability collected in the ORTO-15 and ORTO-15 PL questionnaires. The degree of probability was 0.05 .

\section{Results}


Based on anthropometric data (body weight and height), BMI was determined, which was then compared with the centile meshes for $\mathrm{BMI}$ and according to the resulting groups (BMI above the fifth percentile; BMI equal to or below the fifth percentile), the examined ballerina was divided. Too low BMI values ( $\leq 5$ percentile) were observed in $18 \%$, and in the remaining students, it was within the normal range (from 5 to 85 percentile). The body mass index in the highest number of girls (26\%) was between the 25 and 50 percentile. Too low values of adipose tissue ( $0-2$ percentile) were recorded in $54 \%$ of the girls (Table II).

Table II. Anthropometric index in the research group

\begin{tabular}{|c|c|c|c|c|c|c|}
\hline Anthropometric index & $\begin{array}{l}\text { Body wight } \\
\text { [kg] }\end{array}$ & $\begin{array}{l}\text { Body hight } \\
\text { [m] }\end{array}$ & $\begin{array}{l}\text { BMI } \\
\text { [kg/m2] }\end{array}$ & $\begin{array}{l}\text { Waist } \\
\text { [cm] }\end{array}$ & $\begin{array}{l}\text { Hip } \\
\text { [cm] }\end{array}$ & $\begin{array}{l}\text { WHR } \\
\text { [cm] }\end{array}$ \\
\hline$X \pm S D$ & $39.7 \pm 11.1$ & $1.52 \pm 0.12$ & $16.8 \pm 2.3$ & $63.2 \pm 5.1$ & $78 \pm 10.0$ & $0.42 \pm 0.04$ \\
\hline MIN-MAX & $24.3-78.2$ & $1.33-1.81$ & $12.7-24$ & $53-81$ & $61 \pm 106$ & $0.35 \pm 0.51$ \\
\hline
\end{tabular}

The analysis showed no statistically significant differences $(\mathrm{p}<0.05)$ in the number of people with normal and abnormal BMI between groups of students of different ages. It was observed that the number of girls with too little BMI was a comparable part of all age groups and was about $18 \%$. These differences were statistically significant. Too small waist circumferences $(\leq 5$ centiles) were found in $5 \%$ of all subjects including $6 \%$ of the youngest female students and $2 \%$ of girls aged $13-15$ years. Allfemale respondents aged 16-18 had normal waist circumferences ( $>5$ percentile). The analysis showed that these differences were statistically significant $(p<0.05)$. It was observed that $23 \%$ of the respondents had too small hip circumferences. Among the youngest girls, this group consisted of $39 \%$ of the youngest ballerinas and $18 \%$ of ballerinas from the group of 13-15 years. These differences were statistically significant $(p<0.05)$ - Table III.

Table III. Comparison of an anthropometric index between age groups 


\begin{tabular}{|c|c|c|c|c|c|c|}
\hline \multirow{2}{*}{$\begin{array}{l}\text { anthropometric } \\
\text { index }\end{array}$} & \multicolumn{3}{|l|}{$X \pm S D$} & \multicolumn{3}{|l|}{$\min -\max$} \\
\hline & $\begin{array}{l}10-12 y \cdot(n= \\
210)\end{array}$ & $\begin{array}{l}13-15 y \cdot(n= \\
170)\end{array}$ & $\begin{array}{l}16-18 y \cdot(n= \\
230)\end{array}$ & $\begin{array}{l}10-12 y \cdot(n= \\
210)\end{array}$ & $\begin{array}{l}13-15 y \cdot(n= \\
170)\end{array}$ & $\begin{array}{l}16-18 \text { y. }(n= \\
230)\end{array}$ \\
\hline \multirow[t]{2}{*}{ Body weight $[\mathrm{kg}]$} & $30.7 \pm 4$ & $42.8 \pm 6.5$ & $53.3 \pm 9.8$ & \multirow[t]{2}{*}{$24.3-40.1$} & \multirow[t]{2}{*}{$28.0-56.3$} & \multirow[t]{2}{*}{$36.7-78.2$} \\
\hline & $p<0.05$ & & & & & \\
\hline \multirow[t]{2}{*}{ Body height [m] } & $1.4 \pm 0.05$ & $1.6 \pm 0.07$ & $1.7 \pm 0.07$ & \multirow[t]{2}{*}{$1.33-1.55$} & \multirow[t]{2}{*}{$1.35-1.69$} & \multirow[t]{2}{*}{$1.52-1.81$} \\
\hline & $p<0.05$ & & & & & \\
\hline \multirow[t]{2}{*}{ BMI [kg/m2] } & $15.4 \pm 1.4$ & $17.0 \pm 1.7$ & $19.4 \pm 2.5$ & \multirow[t]{2}{*}{$13.2-19.1$} & \multirow[t]{2}{*}{$14.2-20.7$} & \multirow[t]{2}{*}{$12.7-24.0$} \\
\hline & $p<0.05$ & & & & & \\
\hline \multirow[t]{2}{*}{ waist $[\mathrm{cm}]$} & $61.6 \pm 4.7$ & $62.4 \pm 4.4$ & $67.5 \pm 4.6$ & \multirow[t]{2}{*}{$53.0-70.0$} & \multirow[t]{2}{*}{$57.0-74.0$} & \multirow[t]{2}{*}{$62.0-81.0$} \\
\hline & $p<0.05$ & & & & & \\
\hline \multirow[t]{2}{*}{ hip [cm] } & $69.5 \pm 4.8$ & $80.9 \pm 5.6$ & $90.8 \pm 5.4$ & \multirow[t]{2}{*}{$61.0 \pm 80.0$} & \multirow[t]{2}{*}{$67.0-92.0$} & \multirow[t]{2}{*}{$80.0-106.0$} \\
\hline & $p<0.05$ & & & & & \\
\hline \multirow[t]{2}{*}{ whr [cm] } & $0.44 \pm 0.03$ & $0.39 \pm 0.02$ & $0.41 \pm 0.02$ & \multirow[t]{2}{*}{$0.37 \pm 0.51$} & \multirow[t]{2}{*}{$0.35-0.45$} & \multirow[t]{2}{*}{$0.37-0.45$} \\
\hline & $p<0.05$ & & & & & \\
\hline \multirow[t]{2}{*}{ pal } & $2.0 \pm 0.12$ & $2.06 \pm 01.18$ & $2.13 \pm 0.35$ & \multirow[t]{2}{*}{$1.7-2.2$} & \multirow[t]{2}{*}{$1.8-2.4$} & \multirow[t]{2}{*}{$1.8-2.4$} \\
\hline & $p>0.05$ & & & & & \\
\hline TRAINING (H) & $12 \pm 2.3$ & $14 \pm 4.2$ & $16 \pm 4.5$ & $4.0-18.0$ & $5.0-19.0$ & $5.0-20.0$ \\
\hline
\end{tabular}

There were no statistically significant differences in energy and nutrient content and the realization of nutrition standards between students with normal and too low BMI ( $p>0.05)$ (Table IV).

Table IV. Nutrition status by BMI 


\begin{tabular}{|c|c|c|c|c|c|c|c|c|}
\hline \multirow[t]{2}{*}{ Nutrition status } & \multicolumn{2}{|l|}{$X \pm S D$} & \multicolumn{2}{|c|}{ WHO NORMS [\%] } & \multicolumn{2}{|l|}{$X \pm S D$} & \multicolumn{2}{|c|}{ WHO NORMS [\%] } \\
\hline & $\begin{array}{l}\text { BMI> } \\
5 \mathrm{c} \\
\text { normal } \\
\text { weight }\end{array}$ & $\begin{array}{l}\mathrm{BMI} \leq 5 \mathrm{C} \\
\text { underweight }\end{array}$ & $\begin{array}{l}\text { BMI > } \\
5 \mathrm{c} \\
\text { normal } \\
\text { weight }\end{array}$ & $\begin{array}{l}\mathrm{BMI} \leq 5 \mathrm{C} \\
\text { underweight }\end{array}$ & $\begin{array}{l}\% \mathrm{BF}> \\
2 \mathrm{C} \\
\text { normal } \\
\text { weight }\end{array}$ & $\begin{array}{l}\% \mathrm{BF} \leq 2 \mathrm{c} \\
\text { underweight }\end{array}$ & $\begin{array}{l}\% \text { BF > } \\
2 c \\
\text { normal } \\
\text { weight }\end{array}$ & $\begin{array}{l}\% \mathrm{BF} \leq 2 \mathrm{C} \\
\text { underweight }\end{array}$ \\
\hline \multirow[t]{2}{*}{ ENERGY [kcal] } & $\begin{array}{l}1735 \\
\pm 529\end{array}$ & $1654 \pm 509$ & $\begin{array}{l}70 \pm \\
22\end{array}$ & $71 \pm 24$ & $\begin{array}{l}1768 \\
\pm 537\end{array}$ & $1679 \pm 514$ & $\begin{array}{l}68 \pm \\
19\end{array}$ & $71 \pm 24$ \\
\hline & $p>0.05$ & & $p>0.05$ & & $p>0.05$ & & $p>0.05$ & \\
\hline \multirow[t]{2}{*}{ PROTEIN [g] } & $\begin{array}{l}66.4 \pm \\
20\end{array}$ & $63 \pm 16$ & $\begin{array}{l}157 \pm \\
58\end{array}$ & $174 \pm 61$ & $\begin{array}{l}65 \pm \\
20\end{array}$ & $67 \pm 17$ & $\begin{array}{l}146 \pm \\
55\end{array}$ & $172 \pm 60$ \\
\hline & $p>0.05$ & & $p>0.05$ & & $p>0.05$ & & $p<0.05$ & \\
\hline \multirow[t]{2}{*}{ FAT [g] } & $\begin{array}{l}54 \pm \\
24\end{array}$ & $46 \pm 17$ & $\begin{array}{l}79 \pm \\
36\end{array}$ & $71 \pm 31$ & $\begin{array}{l}55 \pm \\
23\end{array}$ & $51 \pm 24$ & $\begin{array}{l}77 \pm \\
31\end{array}$ & $78 \pm 39$ \\
\hline & $p>0.05$ & & $p>0.05$ & & $p>0.05$ & & $p>0.05$ & \\
\hline \multirow[t]{2}{*}{$\begin{array}{l}\text { CARBOHYDRATES } \\
\text { [g] }\end{array}$} & $\begin{array}{l}244 \pm \\
71\end{array}$ & $246 \pm 84$ & $\begin{array}{l}58 \pm \\
17\end{array}$ & $61 \pm 21$ & $\begin{array}{l}252 \pm \\
74\end{array}$ & $239 \pm 73$ & $\begin{array}{l}57 \pm \\
16\end{array}$ & $59 \pm 20$ \\
\hline & $p>0.05$ & & $p>0.05$ & & $p>0.05$ & & $p>0.05$ & \\
\hline \multirow[t]{2}{*}{ Fibre [g] } & $17 \pm 7$ & $16 \pm 4$ & $\begin{array}{l}84 \pm \\
19\end{array}$ & $87 \pm 11$ & $17 \pm 7$ & $16 \pm 4$ & $\begin{array}{l}84 \pm \\
17\end{array}$ & $89 \pm 14$ \\
\hline & $p>0.05$ & & $p>0.05$ & & $p>0.05$ & & $p>0.05$ & \\
\hline \multirow[t]{2}{*}{ Liquids [I] } & $\begin{array}{l}1.7 \pm \\
0.4\end{array}$ & $1.6 \pm 0.4$ & $\begin{array}{l}94 \pm \\
21\end{array}$ & $87 \pm 18$ & $\begin{array}{l}1.7 \pm \\
0.4\end{array}$ & $1.7 \pm 0.4$ & $\begin{array}{l}92 \pm \\
21\end{array}$ & $93 \pm 21$ \\
\hline & $p>0.05$ & & $p>0.05$ & & $p>0.05$ & & $p>0.05$ & \\
\hline
\end{tabular}

Based on the DQI it was found that $44 \%$ of all respondents reported good, $36 \%$ - satisfactory, and $20 \%$ - bad eating habits (based on the quality of nutrition). Good eating habits were observed in $50 \%$ of the youngest girls, $42 \%$ of the oldest female students, and $28 \%$ of the 13-15 age group. Bad eating habits were reported by $26 \%$ of the $13-15$-year-olds, $16 \%$ of the $16-18$ year-olds, and none of the 10-12-year-olds. The analysis of the data showed that the best eating habits are found in the youngest students. The differences in the results were statistically significant $(p<0.05)$. There were statistically significant differences $(p<0.05)$ in the results concerning students' eating habits depending on the number of training sessions. Good eating habits were observed in $50 \%$ of girls who reported increased physical activity (minimum $15 \mathrm{~h}$ per week) and $30 \%$ of girls who reported moderate physical activity (6-14 h per week). One-third of the girls who trained 6-14 h per week and $6 \%$ of the girls who trained at least $15 \mathrm{~h}$ had bad eating habits. The analysis of the collected results showed that girls with higher physical activity had better eating habits than their peers. The study group did not give the number of training sessions shorter than $6 \mathrm{~h}$ per week. Students' dietary habits were also analyzed concerning their educational experience. Good habits were observed among $60 \%$ of girls with a maximum of 2 years of educational experience. A total of $38 \%$ of students who attended ballet school for the longest period had bad dietary habits. This included $8 \%$ with the shortest educational experience, $10 \%$ who completed 6-8 years of learning, and 5\% who studied for 3-5 years. It was determined that the girls who were at the initial stage of learning at ballet schools had the best dietary habits. Differences in the obtained results were statistically significant $(p<0.05)$.

The analysis of the results obtained with the DQI, which included self-assessment of one's own body, showed that all subjects that considered themselves "too thin" had good eating habits. In contrast, $47 \%$ of the girls who admitted to being "just right" and $29 \%$ of the students who said they were "too fat" had good eating habits. Bad eating habits were observed among $19 \%$ of the students who said they were "too obese" and among $10 \%$ of the students who said they were "just fine. Statistical analysis 
shows that the differences in the results were statistically significant $(p<0.05)$. When analyzing the repetitiveness of the provided responses, 15 questions were included in the ORTO-15 questionnaire. Each question was answered by responding to a 4-point scale. It was possible to recognize orthorexic behavior when the total number of points scored exceeded 20 . The obtained results suggest that six questions $(1,2,4,5,6,10)$ were characterized by a very good repetitiveness of answers given $($ Kappa $=0.91-1,00)$, while the repetitiveness in the remaining nine questions was good (Kappa $=0.51-0.70)$. ORTO-15 PL is a Polish variation of the original ORTO-16 questionnaire Brytek-Matera et al. (2014). It included 9 questions containing cognitive (6 questions) and clinical (3 questions) factors. The cut-off point was set at 24 points. The score below this value was indicative of a tendency to orthorexia. $n$ this case the Kappa test showed very good acceptability for questions 1, 2, 3, 5 (Kappa $=0.91-1.00)$ and good acceptability for the others (Kappa $=0.51-0.70)$.

The genuine risk of eating disorders was observed among 65\% (ORTO-15) and 59\% (ORTO-15 PL) of subjects. This included students with good dietary habits (65\%) and $73 \%$ of students who considered themselves to be obese. Statistical inference showed a relationship between the positive result obtained in the ORTO-15 questionnaire and participants' incorrect perception of their own body $(p<0.05)$ - (Table V). Moreover, it was noted that higher scores in both ORTO scales were obtained by girls whose $\mathrm{BMI}(62 \%)$ and \%BF (56\%) were in the correct range.

Table V. Results of the ORTO-15 questionnaires

\begin{tabular}{|lllllll|}
\hline Results of the ORTO-15 & $\mathbf{X}$ & $\mathbf{\pm S D}$ & $\mathbf{M e}$ & IQR & MIN & MAX \\
\hline ORTO-15 & 35.7 & 5.3 & 36.0 & 7.0 & 24.0 & 51.0 \\
\hline ORTO-15 PL & 19.9 & 4.9 & 19.0 & 7.0 & 10. & 32.0 \\
\hline CUT-OFF POINT & ORT0-15 & & ORTO-15 PL & \\
& $\mathbf{4 0}$ points & & 24 points \\
BELOW & $\mathrm{n}=390(65 \%)$ & $\mathrm{n}=354(59 \%)$ \\
ABOVE & $\mathrm{n}=210(35 \%)$ & $\mathrm{n}=246(41 \%)$ \\
\hline
\end{tabular}

\section{Discussion}

Orthorexia can hide for a long time, as it is based on the pursuit of health and the rightful desire to follow the rules of proper nutrition. It is a model that we should all strive for - only the determination with which people at risk of illness begin to follow it is unhealthy.

Orthorexia rates vary from $6-60 \%$ in the general post-population to as much as $90 \%$ in risk groups, including students [12]. The reason for such large discrepancies is the use of different tools with different psychometric properties (e.g. BOT, ORTO-15), the adoption of different cut-off points for the diagnosis of $\mathrm{ON}$, as well as possible methodological errors. For example, many studies using the BOT or ORTO-15 test indicate a significant incidence of orthorexic behavior among dieticians, doctors, and students of dietetics, medicine, and related disciplines [6-9].

However, the ON study conducted among German students using the BOT test did not reveal significant differences between students of dietetics and students of economics in terms of pathological eating behavior [13]. Significantly lower incidence rates of orthorexia were obtained also in the population of Spanish students when constructing the ORTO-15 questionnaire, indicating that the pathological nature of nutritional health behavior is manifested by a small percentage of students [14].

There are also differences in the incidence of orthorexia among men and women. Some studies indicate a predominance of women [15-20], while others indicate a predominance of males [6, 16], and others do not show significant differences [12, 1621]. The latest survey of Brytek-Matera among over 400 people indicates that the Polish version of the ORTO- 15 test is reliable and a valuable tool to study the obsessive attitude to health and proper nutrition in the Polish population of women and men [16-20]. 
Other studies have also observed a link between orthorexia and healthy lifestyles and groups that adhere to all healthpromoting principles. Agopyan [22] conducted a study to establish a link between orthorexia and body composition of female students at the University of Marmara. The study participants were students whose results of the ORTO-15 questionnaire and EAT-40 attitude test indicated the presence of orthorexia. The evaluation of respondents' body composition indicators (bioelectric impedance on a Tanita SC-330 device) showed that there was no significant difference between the EAT-40 and ORT0-15 results in terms of body composition. The vast majority of respondents (70.6\%) had high ORTO-15 results, and there was a significant negative correlation between EAT-40 and ORTO-15 results $(p<0.05)$. The final results of data analysis showed that although abnormal orthorexia tendencies were common among female students, they were able to maintain correct body composition. Similarly, a study by Haddad [23] showed that health sciences students, especially nutrition and dietetics students, showed a higher incidence of eating disorders. The study involved 176 undergraduate students from the Faculty of Nutrition and Dietetics. The study monitored food consumption and evaluated the frequency of eating owing to emotion and stress (EADES). Among the students participating in this study, $4.5 \%$ showed food dependency, and $68.2 \%$ showed orthorexia. No differences were observed between men and women in terms of food dependence and orthorexia. Students with orthorexia had increased BMI. Orthorexic students consumed more low-energy products, including vegetables, and less high-energy products (meat and fats). Multiple linear regression analysis showed that orthorexic behavior was associated with increased $\mathrm{BMI}$, waist circumference, and energy intake. Lower BMI was associated with the ability to cope with EADES. In this study, similar results of the TFEQ-13 test were obtained. Malmborg et al. [24] conducted a study to compare the state of health, physical activity, and incidence of orthorexia among physical education and management students. Respondents completed a short quality of life assessment questionnaire (SF-36), International Physical Activity Questionnaire (IPAQ), and ORTO-15 questionnaire. Out of 188 students, 144 (76.6\%) had an ORTO-15 score that indicated orthorexia, 84.5\% of which were physical education students. Orthorexia combined with the high level of physical activity was more frequently observed in men studying physical education than in women studying physical education (45.1\% vs. $8.3 \%)$. This confirms the hypothesis in our study that people who intensively practice sport may have significantly higher exposure to orthorexia than those with lower levels of physical activity. Similarly, a study by Grammatikopoulou et al. [24] showed that health sciences students, especially nutrition and dietetics students, showed a higher incidence of eating disorders. The study involved 176 undergraduate students from the Faculty of Nutrition and Dietetics in Greece. The study monitored food consumption and evaluated the frequency of eating owing to emotion and stress (EADES). Among the students participating in this study, $4.5 \%$ showed food dependency, and $68.2 \%$ showed orthorexia. No differences were observed between men and women in terms of food dependence and orthorexia. Students with orthorexia had increased BMI. Orthorexic students consumed more low-energy products, including vegetables, and less high-energy products (meat and fats). Multiple linear regression analysis showed that orthorexic behavior was associated with increased BMI, waist circumference, and energy intake. Lower BMI was associated with the ability to cope with EADES. In this study, similar results of the TFEQ-13 test were obtained.

The results obtained in the studies discussed above are consistent with the results obtained in the own study. In the conducted study, it was observed that $59-65 \%$ of the respondents showed orthorexic behaviors that were associated with excessive attention to their body shape. The discrepancies in the obtained results result from the use of two scales: the traditional ORTO15 and the Polish ORTO-15 PL scale, which has been revised and its reliability has been confirmed for use in Polish conditions.

To sum up the above, it should be stressed that orthorexia is a disorder that occurs in human populations with different intensities. Many scientific studies discuss whether it should be included in the ICD and DSM list [25-26].

\section{Conclusions}

Summarizing the results of own research and the results of other authors, it can be concluded that: Most of the girls represented normal eating habits measured by the DQI scale, and anthropometric measurements are also satisfactory, with only 13-15-year-olds showing deviations. In the research group, there is a high risk of the possibility of orthorexia. This is particularly visible in the group of girls whose eating habits were assessed as good and in the group of ballerinas who consider themselves obese. Moreover, it was noted that BMI and adipose tissue level in the risk group was at the correct level. 


\section{Declarations}

Ethics approval and consent to participate: the research complies with the provisions of the Helsinki Declaration and local regulations of the Bioethical Commission of the Silesian Medical University in Katowice; the Committee on Publication Ethics (COPE) regulations were followed in the study;

Consent for publication: all the mentioned co-authors of the work, as well as the relevant authorities of the scientific institutions in which the work was created, after reading its contents, agree to the publication.

Availability of supporting data: not applicable

The datasets generated and/or analysed during the current study are not publicly available due [We do not want to share the data because of its size, which includes other aspects that we intend to continue to study.] but are available from the corresponding author on reasonable request.

Competing interests: not applicable

Funding: This research received no external funding.

Authors' contributions: Conceptualization, MG; Investigation: MG and KKK; Methodology, MG and KKK; Data curation: MG and ABD ; Writing - Original Draft Preparation, MG; Writing - Review \& Editing, MG and KKK and ABD; Supervision - KSN; Project Administration - KKK.

Acknowledgements: not applicable

Conflict of interest statement: The authors declare no conflict of interest.

\section{References}

1. Dittfeld A, Koszowska A, Fizia K, Ziora K. Ortoreksja - nowe zaburzenie odżywiania. Ann Acad Med Siles2013; 67(6): 393399.

2. Dittfeld A, Gwizdek K, Jagielski P, Brzęk J, Ziora K. A Study on the relationship be-tween orthorexia and vegetarianism using the BOT (Bratman Test for Orthorexia). Psych Pol 2017; 31(6): 1133-1144, DOI: https://doi.org/10.12740/PP/75739.

3. Nowogrodzka A, Piasecki B. Eating disorder - gender differences. Now Lek 2012; 81(4): 381-385.

4. Dunn TM, Bratman S. On orthorexia nervosa: A review of the literature and proposed diagnostic criteria. Eat Behev 2016; 21: 11-17, DOI: https://doi.org/10.1016/j.eatbeh.2015.12.006.

5. Bratman S, Knight D. Health Food Junkies: Orthorexia Nervosa: Overcoming the Obsession with Healthful Eating. New York: Broadway 2000.

6. Vuillier L, Robertson S, Greville-Harris M. Orthorexic tendencies are linked with difficulties with emotion identification and regulation. J Eat Disord 2020; 8: 15 https://doi.org/10.1186/s40337-020-00291-7

7. Bartel SJ, Sherry SB, Farthing GR, Stewart SH. Classification of Orthorexia Nervosa: Further evidence for placement within the eating disorders spectrum. Eat Behav 2020; 38:101406. doi: 10.1016/j.eatbeh.2020.101406. Epub 2020 Jun 6. PMID: 32540715.

8. Kubiak J, Różańska D, Regulska-Ilow B, Mandecka A. Ocena jakości diet studentek dietetyki na podstawie wskaźnika dqi (diet quality index). Bromat Chem.Toksykol 2015; 40(8): 429-432.

9. Frackiewicz J, Roszkowski W, Brzozowska A, Kałuza J. Diet quality and mortality in elderly people living in Warsaw Region. Przegl Epidemiol 2010; 64(1): 119-125.

10. Dunn TM, Gibbs J, Whitney N, Starosta A. Prevalence of orthorexia nervosa is less than $1 \%$ : data from a US sample. Eat Weight Disord 2017; 22(1): 185-192. doi: 10.1007/s40519-016-0258-8. Epub 2016 Feb 22. PMID: 26902744. 
11. Brytek-Matera A, Krupa M, Poggiogalle E, Donini LM. Adaptation of the ORTHO-15 test to Polish women and men. Eat Weight Disord 2014; 19(1): 69-76. doi: 10.1007/s40519-014-0100-0. Epub 2014 Erratum in: Eat Weight Disord. 2014 Jun;19(2):271. PMID: 24448996.

12. Depa J, Schweizer J, Bekers SK, Hilzendegen C, Stroebele-Benschop N. Prevalence and predictors of orthorexia nervosa among German students using the 21-item-DOS. Eat Weight Disord 2017 ;22(1):193-199. doi: 10.1007/s40519-016-0334-0. Epub 2016 Oct 19. PMID: 27761853.

13. Tremelling K, Sandon L, Vega GL, McAdams CJ. Orthorexia Nervosa and Eating Disorder Symptoms in Registered Dietitian Nutritionists in the United States. J Acad Nutr Diet 2017; 117(10): 1612-1617. doi: 10.1016/j.jand.2017.05.001. Epub 2017 Jun 15. PMID: 28624376; PMCID: PMC5623148.

14. Barrada JR, Roncero M. Bidimensional Structure of the Orthorexia: Development and Initial Validation of a New Instrument. Ann de Psicol 2018; 34(2): 283-291 DOI: https://doi.org/10.6018/analesps.34.2.299671.

15. Rogoza R, Hallit S, Soufia M, et al. Validation of the Arabic version of the Dusseldorf Orthorexia Scale (DOS) among Lebanese adolescents. J Eat Disord 2021; 9 , :130 https://doi.org/10.1186/s40337-021-00488-4

16. Brytek-Matera A. Orthorexia nervosa - An eating disorder, obsessive-compulsive disorder, or disturbed eating habit? Arch Psychiat Psychoth 2012; 1(1): 55-60.

17. Parra Carriedo A, Tena-Suck, A, Barajas-Márquez M, et al. When clean eating isn't as faultless: the dangerous obsession with healthy eating and the relationship between Orthorexia nervosa and eating disorders in Mexican University students. J Eat Disord 2020; 8: 54 https://doi.org/10.1186/s40337-020-00331-2

18. Brytek-Matera A, Donini LM, Krupa M, Poggiogalle E, Hay P. Orthorexia nervosa and self-attitudinal aspects of body image in female and male university students. J Eat Disord 2015; 3(1): 1-8 DOI: https://doi.org/10.1186/s40337-015-0038-2.

19. Brytek-Matera A, Fonte ML, Poggiogalle E, Donini LM, Cena H. Orthorexia nervosa: relationship with obsessive-compulsive symptoms, disordered eating patterns and body uneasiness among Italian university students. Eat Weight Disord 2017; 22(4): 609-617. doi: 10.1007/s40519-017-0427-4. Epub 2017 Aug 24. PMID: 28840493.

20. Brytek-Matera A, Gramaglia C, Gambaro E, Delicato C, Zeppegno P. The psychopathology of body image in orthorexia nervosa. J Psychopath 2018; 24: 122-140.

21. Donini LM, Marsili D, Graziani MP, Imbriale M, Cannella C. Orthorexia nervosa: a preliminary study with a proposal for diagnosis and an attempt to measure the dimension of the phenomenon. Eat Weight Disord 2004; 9(2):151-7. doi: 10.1007/BF03325060. PMID: 15330084.

22. Agopyan, A. et al. The relationship between orthorexia nervosa and body composition in female students of the nutrition and dietetics department. Eat Weight Disord 2019; 24(2): 257-266. DOI: 10.1007/s40519-018-0565-3.

23. Haddad C, Obeid S, Akel M, Honein K, Akiki M, Azar J, Hallit S. Correlates of orthorexia nervosa among a representative sample of the Lebanese population. Eat Weight Disord 2019; 24(3):481-493. doi: 10.1007/s40519-018-0631-x. Epub 2019 Jan 2. PMID: 30603929.

24. Malmborg J, Bermander A, Olsson MC, Bergman S. Health status, physical activity, and orthorexia nervosa: A comparison between exercise science students and business students. Appetite 2017; 1(109): 137-143. doi: 10.1016/j.appet.2016.11.028.

25. DSM-5 (2013): https://www.psychiatry.org/psychiatrists/practice/dsm [on-line: 04.02.2022].

26. ICD-11 (2018): https://www.who.int/classifications/classification-of-diseases [on-line: 04.02.2022].

27. Ryman FVM, Cesuroglu T, Bood ZM, Syurina EV. Orthorexia Nervosa: Disorder or Not? Opinions of Dutch Health Professionals. Front Psychol. 2019 Mar 15;10:555. doi: 10.3389/fpsyg.2019.00555. PMID: 30930821; PMCID: PMC642871 